\title{
O bacharel em DIREITO COMO O HOMEM PÚBLICO BRASILEIRO'
}

\author{
Humberto Dantas \\ Pesquisador do IDESP e professor do Centro Universitário São Camilo \\ E-mail: hdantas@usp.br
}

\section{Resumo}

A carreira do bacharel em Direito é, e sempre foi, a que mais está presente na política nacional. A composição da Câmara dos Deputados ao longo da história espelha essa realidade desde o Império até os dias de hoje. Tal representação, no entanto, teve seu peso alterado, sobretudo durante - Império e após a promulgação da Constituição de 1988. O presente artigo tem por objetivo mostrar que a representação dos bacharéis em Direito na política nacional, representada pela contagem dos membros da Câmara dos Deputados, guarda ligação com a adoção de políticas de ensino superior pelos mais diferentes governos ao longo de aproximadamente dois séculos de história.

Palavras-chave: classe política, ensino jurídico, políticas de ensino superior

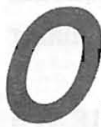

ireito é e sempre foi a carreira mais representada na política nacional. Mesmo antes de o Brasil tornar-se independente e contar com cursos jurídicos, os bacharéis em Direito já ocupavam papel relevante na burocracia estatal. O objetivo deste artigo é quantificar esta presença ao longo de 180 anos de história e mostrar que duas alternativas nas políticas de ensino superior no país exerceram influência sobre o índice de participação dos bacharéis em Direito na Câmara dos Deputados.

' O tema do presente trabalho é parte da dissertação de mestrado defendida em $22 /$ 05/2002, Ensino jurídico e classe política. 
À medida que a sociedade brasileira foi-se desenvolvendo e tornando-se complexa, mais necessária se fez a presença de uma classe de letrados. Por isso, o diplomado no curso jurídico da Universidade de Coimbra (Portugal) destacou-se na política, sendo caracterizado como o brasileiro que cruzou o oceano em busca de instrução. Segundo Simões Neto (1983), o curso de Direito da Metrópole formava, por sua própria natureza, profissionais da lei que fariam parte dos quadros dirigentes das colônias ${ }^{2}$. Além disso, nessas escolas graduaram-se os docentes dos cursos inaugurados no Brasil em 1827, e grande parte dos políticos que tomaram assento no governo pós-independência ocupando-os até meados do século XIX ${ }^{3}$.

A história do ensino das leis no Brasil e da presença desses bacharéis em nossa política deve ser contada a partir de Portugal. A expansão da colônia gerou um aumento significativo de brasileiros na Universidade de Coimbra. No século XVI, formaram-se lá 13 brasileiros, no século seguinte foram 354 e no século XVIII 1.752 (VENÂNCIO FILHO, 1982). Dos 622 estudantes da colônia ${ }^{4}$ que obtiveram diplomas de nível superior na metrópole, entre 1776 e 1830, 78,6\% freqüentaram a escola de Direito.

Em 1823, período anterior à inauguração de cursos jurídicos no Brasil, os deputados formados em Direito já eram maioria na Assembléia Constituinte. Simões Neto (1983) mostra que 65\% dos 90 parlamentares possuíam formação jurídica. Rodrigues (1974) afirma que "quase todos" os deputados eram brasileiros natos e a grande maioria era constituída de bacharéis em Direito, juizes e desembargadores, sendo consensual a constatação de que o diploma em leis já em 1823 qualificava a maior parte dos representantes políticos nacionais.

$\mathrm{Na}$ legislatura posterior à Assembléia Constituinte (de $1826 \mathrm{a}$ 1829), o Poder Legislativo foi composto por $41,5 \%$ de deputados e $50 \%$

\footnotetext{
${ }^{2}$ A respeito do curso de Direito da Universidade de Coimbra, Simões Neto (1983) faz, em sua obra, pormenorizada descrição acerca de sua fundação, funcionamento, história e até mesmo características.

${ }^{3}$ Os brasileiros assumiram inclusive importantes postos na burocracia estatal da metrópole.

${ }^{4}$ A segunda carreira mais freqüentada foi Filosofia / Teologia com 42 diplomados, ou $6,7 \%$ do total.
} 
de senadores advindos das escolas jurídicas. Anterior à formação das primeiras turmas nacionais, esse período continuou marcando a presença significativa do diploma obtido em Coimbra na política brasileira (BARRETO, 1978).

\section{A formação nacional dos políticos}

Em 1822, após a proclamação da Independência, a instalação de cursos jurídicos no Brasil passou a fazer parte da pauta de discussões parlamentares. Não foi pequena a polêmica gerada em torno do oferecimento deste tipo de ensino. Um dos principais objetivos da medida era libertar definitivamente o país dos laços de dependência para com Portugal. De acordo com Adorno (1988), além da localização das escolas - parlamentares de todas as províncias julgavam suas cidades mais aptas a sediar tais instituições - outros fatores geraram discórdia. Os principais tópicos de desacordo foram o ensino ou não do Direito Romano, a origem dos fundos mantenedores dos cursos e a requisição de professores à antiga Metrópole ${ }^{5}$. Após intensos debates, o projeto para a criação de um curso em São Paulo, apresentado pelo Visconde de São Leopoldo em 14 de junho de 1823, foi aprovado em 4 de novembro. A emenda de Araújo Lima estabeleceu também a inauguração de uma faculdade de Direito em Olinda-PE.

Em 12 de novembro do mesmo ano, a Assembléia Constituinte foi dissolvida e a tentativa de inauguração dos cursos jurídicos perdeuse na história. Em 25 de março de 1824, com a outorga da Constituição, o assunto voltou à pauta. Em janeiro de 1825, o imperador determinou a criação de uma escola provisória na capital do país, então sediada no Rio de Janeiro (ADORNO, 1988). A instituição não chegou a funcionar, mas os estatutos preparados pelo Visconde de Cachoeira serviram de base para uma nova rodada de discussões que tiveram início com a instalação da Assembléia Geral Legislativa, em 1826. Em agosto desse mesmo ano, encerrados os debates na Assembléia Geral, a proposta foi enviada ao Senado que, por sua vez, iniciou as discussões em maio

${ }^{5}$ Com semelhante riqueza de detalhes, Simões Neto (1983) percorre os caminhos de Adorno para descrever a fundação dos cursos jurídicos nacionais. 
seguinte e aprovou o projeto em 4 de julho. No dia 11 de agosto de 1827, com a lei sancionada por Dom Pedro I, foi autorizada a criação de dois cursos jurídicos no Brasil - um em São Paulo e outro em Olinda-PE.

\section{A presença do diploma jurídico no Império}

Há acordos nos estudos sobre a assertiva de que a decisão do governo imperial em autorizar o ensino de Direito no Brasil estava relacionada principalmente à composição de nossa elite política ${ }^{6}$. Os discursos de várias personalidades da época, citadas por Venâncio Filho (1982), salientam esse objetivo. O Visconde de Cachoeira, responsável pelos estatutos provisórios dos cursos, aponta como função principal destas instituições a formação de "dignos deputados e senadores". O parlamentar Cunha Barbosa, por sua vez, esclarece que as escolas deveriam ensinar doutrinas ao legislador e ao homem de Estado, lembrando que o Brasil independente precisava formar cidadãos aptos a substituir os atuais membros do Poder Legislativo.

Adorno (1988) afirma que paralelamente ao surgimento dessa classe política dirigente emergiram os mais diversos personagens do cenário jurídico e da burocracia estatal, como magistrados, desembargadores, diplomatas etc. Além disso, esses cursos revelaramse enormes celeiros de intelectuais, escritores, artistas e jornalistas: "As Academias de Direito resumem, durante todo o período monárquico e boa parte de nossa vida republicana, toda a vida cultural e política do país" (SIMÕES NETO, 1983, p.96).

Presentes na política nacional antes mesmo da inauguração de nossas escolas jurídicas, os bacharéis em Direito ganharam ainda mais destaque a partir do funcionamento desses cursos no Brasil. De 1832, ano em que se formou a primeira turma, até o final do Império, houve uma significativa expansão da participação desses cidadãos nos postos políticos. Na legislatura de 1834 já estão presentes na Assembléia Geral deputados formados pelas academias de São Paulo

\footnotetext{
${ }^{6}$ Muitos dos estudiosos citados na bibliografia tratam o assunto brevemente. Com maior rigor de detalhes destacam-se Bastos (1997), Adorno (1988), Carvalho (1981), Venâncio Filho (1982) e Simões Neto (1983).
} 
e de Olinda e, até meados do século XIX, estes diplomados substituiriam, completamente, os representantes com formação coimbrana. Dividindo a análise por legislaturas até 1858, Simões Neto (1983) demonstra a crescente presença entre os deputados dos diplomados em cursos de leis: $1826-1829-42,4 \% 7$; 1830-1833 - 40,0\%; 1834-1837-39,3\%; 1838-1841 - 65,2\%; 1842-1844 - 51,4\%; 1845-1847 $51,4 \% ; 1848-1852-56,5 \%$; e $1853-1858-81,2 \%$.

Carvalho (1981) também analisa a trajetória do bacharel em Direito na Assembléia Geral durante o Império. Em 1826, do total de deputados, $1 \%$ era de advogados, $8 \%$ de bacharéis e $27 \%$ de magistrados, perfazendo um total de $36 \%$. Em 1886, quase 60 anos após a fundação dos cursos jurídicos, observa-se claramente os efeitos de sua implantação: $12 \%$ dos deputados eram advogados, $46,4 \%$ eram bacharéis e $6,4 \%$ eram magistrados, perfazendo um total de $64,8 \%$. O crescente aumento da participação desses profissionais nos cargos políticos contrasta com a diminuição da presença de indivíduos formados em outras áreas, demonstrando que o diploma jurídico ocupou rapidamente o cenário político nacional do século XIX ${ }^{8}$.

Com relação a outros cargos exercidos durante o Império e que podem confirmar a ampla participação dos bacharéis em Direito na vida política do país, Simões Neto (1983) analisa o Conselho de Estado, formado por doze membros vitalícios indicados pelo Imperador. Entre 1842 e 1889, $80,7 \%$ deles tinham formação jurídica. Carvalho (1981) demonstra a consolidação dos diplomados dessa carreira nos cargos de Ministro do Império ${ }^{9}$ e Senador, dividindo o reinado em cinco fases distintas. Os dados indicam que antes mesmo da formação das primeiras turmas dos cursos jurídicos nacionais os bacharéis em Direito já ocupavam mais da metade das cadeiras disponíveis nos ministérios $(51,3 \%)$ e no Senado

\footnotetext{
${ }^{7}$ Barreto (1978) diverge de Simões Neto, afirmando que a primeira legislatura registrou $41,5 \%$ de deputados formados em Direito.

${ }^{8}$ Como fator relevante para seu argumento, José Murilo de Carvalho destaca a substituição, na carreira política, do magistrado pelo bacharel em Direito durante o Império. Ao nosso propósito, no entanto, cabe apenas destacar a presença significativa do diploma jurídico nas carreiras públicas.

9 José Murilo de Carvalho considera o cargo de Ministro o posto político mais importante do Império. A escolha desses profissionais era baseada em decisão pessoal do imperador.
} 
$(61,2 \%)$. Com a consolidação das escolas jurídicas, entre 1840 e 1853, a hegemonia desses profissionais expandiu para $85 \%$ (ministros) e $78,1 \%$ (senadores). $\mathrm{O}$ ponto mais alto desta participação ocorreu no período de 1853 a 1871 no Senado $(93,3 \%)$ e de 1871 a 1889 nos ministérios (86\%).

Segundo interpretação bastante aceita, a presença dos bacharéis em Direito na política nacional tinha o objetivo claro de homogeneizar as ações e conferir legitimidade ao governo imperial (ADORNO, 1988). Entretanto, desenvolveram-se no interior das duas academias "idéias novas", bem como todo e qualquer movimento crítico e mudancista. Venâncio Filho (1982), confirmando essa hipótese, descreve o apoio dos bacharéis à federalização do Estado nacional, à proclamação da República, ao movimento abolicionista etc. O autor deixa claro que São Paulo e Pernambuco, com suas academias, foram centros de um "admirável" movimento intelectual idealista, cujo objetivo era colocar em prática no Brasil a "idéia nova". Desses cursos saíram os mais "ardentes" abolicionistas ${ }^{10}$, os mais "convencidos" federalistas e os mais "impetuosos" republicanos".

Adorno (1988) afirma que a atenção dispensada à causa pública mostra que a militância política conquistou o espaço reservado ao ensino de Direito nas escolas. Os cursos jurídicos profissionalizaram a política, monopolizando as discussões dos assuntos nacionais. Assim, as escolas de Direito impediram a heterogeneidade das elites, respondendo positivamente às intenções do Estado de centralizar a administração política nacional.

\section{A participação do bacharel em Direito na República}

Em 1891, após a proclamação da República, o governo federal pôs fim ao controle e ao monopólio das escolas de Direito de São Paulo

\footnotetext{
${ }^{10}$ Joaquim Nabuco, renomado abolicionista, dizia que a faculdade de Direito de São Paulo era uma "ante-sala" da Câmara (VENÂNCIO FILHO, 1982).

"De acordo com Simões Neto (1983), havia diferenças na formação dos bacharéis de Olinda/Recife e de São Paulo no que diz respeito ao caráter político desta instrução. No caso da Província sulista, o aspecto liberal esteve mais presente, o que pode ser explicado em parte pela coesão de seus estudantes em torno de questões relevantes para o cenário nacional.
} 
e de Recife ${ }^{12}$. Apesar da mudança de regime e do abandono explícito das intenções oficiais em relação aos cursos jurídicos, a presença dos bacharéis em Direito na política nacional continuou marcante.

Falcão Neto (1978) afirma que até as primeiras décadas do século XX o compromisso primordial das escolas jurídicas foi a formação dos quadros estatais, a despeito das alterações ocorridas na política de ensino superior e no sistema de governo. Efetivamente, Simões Neto (1983) demonstra por meio de números que o período de 1889 a 1930 (República Velha) representou a continuidade da presença dos titulados em Direito na política nacional.

Apesar da continuada hegemonia do diploma jurídico na política republicana ${ }^{13}$, o fim do reinado e a escolha de um militar para a presidência alteraram a relação dessa carreira com o poder. Nos primeiros anos da República grupos militares se mostraram contrários à presença dos bacharéis em Direito na "condução" do país ${ }^{14}$. De acordo com Simões Neto (1983), os discursos das forças armadas proclamavam que muitos dos males nacionais deveriam ser imputados ao "bacharelismo": "À cultura bacharelística, ineficiente, idealista, afastada da autêntica realidade nacional, deveria suceder outra, voltada para esta realidade e com a finalidade de eficiência. O que o Brasil precisa são técnicos e não bacharéis".

Como resultado dessa animosidade, entre 1889 e 1899 o bacharel em Direito teve o mais baixo índice de representação no Poder Legislativo (Câmara dos Deputados) durante a República Velha (1889-1930); cerca de $49 \%$ de participação nas três primeiras legislaturas, em comparação com os 58,9\%, em média, nas seis legislaturas seguintes. Esses espaços foram ocupados principalmente por militares.

Com o advento da Constituição de 1891, os parlamentares do Senado perderam a vitaliciedade e o número de representantes ligados aos cursos jurídicos caiu para $48,7 \%$, ante os $75 \%$ de representação no Império. Entre os ministros, o índice de $43,8 \%{ }^{15}$ confirma a mesma tendência:

\footnotetext{
${ }^{12}$ Em 1854 a escola de Direito de Olinda foi transferida para Recife. Venâncio Filho (1982) explica os motivos deste deslocamento.

13 Sobretudo em cargos eletivos.

${ }^{14}$ Neste mesmo sentido, Venâncio Filho (1982) apresenta argumentos que explicam este movimento contrário aos bacharéis em Direito.

${ }^{15}$ Excetuando-se os ministros de pastas militares, este percentual ultrapassa os 60 pontos (SIMÕES NETO, 1983).
} 
decréscimo na participação, se comparado ao período entre 1822 e 1889 $(72,5 \%)$, ainda que mantida a liderança. Somente os militares ganharam espaço, não tendo se destacado na política nenhuma outra carreira.

Findados os primeiros anos da República e a ditadura comandada por Getúlio Vargas entre 1937 e 1945, a Assembléia Constituinte formada em 1946 ainda refletia uma presença significativa de bacharéis em Direito. Braga (1998) informa que 55,3\% dos parlamentares tinham diploma jurídico ${ }^{16}$.

\section{O regime de 64 e os bacharéis em Direito}

Durante aproximadamente vinte anos (entre 1964 e 1985), o país viveu sob o autoritarismo militar. Nesse período, os bacharéis em Direito reclamaram a perda de poder, responsabilizando o Executivo por entregar o controle burocrático da nação a economistas e engenheiros. Os novos critérios de recrutamento da classe dirigente apoiavam-se em dois princípios: a necessidade de afastar do poder os juristas, que poderiam contestar a legalidade do regime; e a preferência por profissionais de carreiras vistas como dinâmicas e modernas, que auxiliassem no desenvolvimento econômico e tecnológico do país, bandeiras utilizadas para legitimar o governo ${ }^{17}$.

Nota-se que pela terceira vez ${ }^{18}$, em cerca de cinqüienta anos, os bacharéis em Direito protestaram contra a tentativa dos militares de afastá-los do cenário político. Se em um primeiro momento (18891930) as ações das forças armadas estavam centradas nas críticas ao suposto atraso causado pela excessiva presença dos juristas no poder,

\footnotetext{
${ }^{16}$ Este percentual pode ser ainda maior, uma vez que, em seu estudo, o autor contabilizou somente um título acadêmico para cada deputado - aquele que de alguma forma estivesse mais relacionado ao exercício profissional.

${ }_{17}$ O problema de substituir parte dos bacharéis em Direito por economistas já despertava a atenção de autores que focaram seus estudos em épocas mais remotas. Venâncio Filho (1982) e Buarque de Holanda (1997) mostram que a presença do bacharel em Direito na política imperial muitas vezes explica a ausência de preocupação com problemas econômicos, dando-se ênfase a uma cultura voltada quase que exclusivamente para a retórica e a eloquiência.

${ }^{18}$ A primeira, como vimos, ocorreu após a Proclamação da República, de acordo com o trabalho de Simões Neto (1983). E a segunda durante os anos 30 do século XX.
} 
durante o regime militar (1964-1985) a repressão não atingiu um segmento profissional específico. Não se pode afirmar que as carreiras jurídicas tenham sido as mais reprimidas pelo autoritarismo. Há, contudo, durante esse período, uma reorientação nos quesitos considerados importantes para a composição do grupo encarregado de definir as políticas públicas.

Apesar de o regime militar atingir a todos, alguns autores ligados aos cursos de Direito relatam as conseqüências deste governo para as carreiras jurídicas, especificamente. Parece consensual, entre eles, que o autoritarismo alijou do poder uma parcela significativa dos bacharéis.

José Eduardo Faria e Cláudia de Lima Menge (1979), por exemplo, sustentam que o AI-5 marcou a substituição dos advogados que faziam parte da máquina estatal por tecnocratas capazes de levar o Estado a assumir funções sociais, econômicas e culturais, além das liberais, e não só no campo jurídico-político. O bacharel em Direito deveria conscientizar-se de que seu papel como "instrumento do poder" havia chegado ao fim e que o momento seria de ruptura da eterna integração com as elites dominantes.

Os autores mostram que, por meio da massificação do ensino jurídico, o governo instaurou uma prática pedagógica voltada unicamente para a memorização de normas, distanciando o bacharel em Direito de seu caráter contestador. Ao Estado interessava manter esta estrutura, uma vez que advogados litigantes eram vistos como uma ameaça ao desenvolvimento do país. Dessa forma, o ensino jurídico, desvinculado de seu papel de assessor e preso à tradição secular de sua fundação, perdeu parte de sua função na sociedade.

Segundo Venâncio Filho (1982), o processo de desenvolvimento econômico ocorrido no regime autoritário alterou por completo a situação dos profissionais da lei no país. Em razão da formação inadequada que passou a receber nas escolas jurídicas, o bacharel em Direito foi facilmente substituído por engenheiros, economistas e administradores, restando aos advogados o isolamento.

Falcão Neto (1978, p.67) reconhece a importância histórica dos bacharéis em Direito na política nacional, mas destaca a perda de espaço destes profissionais durante o regime militar. "A momentânea desimportância de hoje, apontada pela quase unanimidade dos 
bacharéis, não lhes acarreta a desimportância histórica. A criação dos cursos jurídicos confunde-se com a formação do Estado Nacional".

Apesar de alijados da burocracia estatal durante o período militar, os bacharéis em Direito mantiveram sua posição como a carreira mais representada em cargos eletivos. Na legislatura de 1967 a 1970, 49,5\% dos parlamentares da Câmara dos Deputados advogavam, ou seja, possuíam ligações com os cursos jurídicos ${ }^{19}$. Entre as carreiras que alcançaram índices de representatividade em cargos eletivos superiores a $10 \%$ encontramos o magistério $(17,15 \%)$, as atividades industriais $(13,29 \%)$ e a agricultura $(12,56 \%)$ (CÂMARA DOS DEPUTADOS, 1968$)^{20}$. Na legislatura seguinte - de 1971 a 1975 -, a participação de bacharéis em Direito cresceu 7\%, ocupando mais da metade das cadeiras disponíveis $(52,8 \%)$. Simões Neto (1983) constata que a tradição das escolas de São Paulo (12 parlamentares) e Pernambuco (13 deputados) ainda era marcante.

No que diz respeito à ocupação dos ministérios, os bacharéis em Direito, efetivamente, perderam a hegemonia para as forças armadas. Tradicionalmente composto por membros de confiança do presidente ou do partido governista, durante o mandato de Geisel o gabinete contou com apenas $21,1 \%$ de ministros com formação jurídica e $47,4 \%$ de militares. No exercício seguinte, sob o comando do general Figueiredo em 1982, quando o país passou por um processo de abertura política, lenta e gradual, o número de bacharéis em Direito subiu para $27,3 \%$ e o de militares caiu para $40,9 \%$.

\section{Do período de redemocratização até a atualidade}

Os diplomados em Direito continuaram a se destacar na política nos anos que sucederam o fim do regime autoritário, a despeito das alterações políticas e acadêmicas ocorridas. Apesar de a Constituição de 1988 ter democratizado o acesso aos cargos

${ }^{19}$ Para tornar o argumento ainda mais consistente em relação ao fato de que os bacharéis em Direito continuaram sendo maioria na Câmara de Deputados, é importante frisar que o $\mathrm{MDB}$, partido de oposição ao regime, não detinha a seus serviços todos os bacharéis que ocupavam cargos políticos, que pertenciam também à ARENA, partido do governo.

${ }^{20}$ É importante observar que nestes três casos não está descartada a possibilidade destes deputados serem também bacharéis em Direito. 
públicos ${ }^{21}$ e de ter ocorrido uma grande diversificação no cenário acadêmico, que passou a ser composto por uma significativa variedade de cursos, os bacharéis em Direito ainda constituem a maioria, sobretudo no parlamento nacional.

Martins Rodrigues (1987) mostra que, contabilizadas todas as profissões dos deputados responsáveis pela Constituição de 1988, os advogados representavam $35 \%$ do total. Dentre os senadores da Constituinte, pertencentes à $48^{\mathrm{a}}$ legislatura (1987-1991), aproximadamente $53 \%$ declararam ter estudado em escolas de Direito (SENADOFEDERAL, 1987).

Os dados aqui apresentados resumidamente mostram que a presença do bacharel em Direito na política nacional foi marcante ao longo de toda a história do país independente, sendo esta a carreira mais representada na vida pública. Mesmo com o relativo afastamento desses profissionais da esfera burocrática estatal em conseqüência de movimentos distintos liderados por militares, o título jurídico manteve sua supremacia frente aos demais diplomas, passando de uma situação em que havia uma intenção em mantê-lo para uma tradição que, baseada em outros fatores, persiste até os dias de hoje.

Nas últimas três legislaturas na Câmara dos Deputados, incluindo a que tomou posse em 2003, o bacharelado em Direito continua figurando como o título acadêmico mais representado: em média $36 \%$ dos parlamentares freqüentaram cursos jurídicos.

\section{A presença do Bacharel ao longo dos anos}

Levando-se em consideração os dados até aqui apresentados, o gráfico 1 mostra como a participação dos bacharéis em Direito na Câmara dos Deputados oscilou ao longo de 180 anos de história. O próximo passo deste trabalho será mostrar que essa participação guarda relação com dois

${ }^{21}$ De acordo com a Constituição Federal de 1988, somente a alfabetização, o alistamento militar (para homens) e alguns limites de idade são requisitos para a elegibilidade.

${ }^{22}$ Este é o mais baixo índice de representatividade registrado até então, inferior, inclusive, ao verificado durante os períodos em que os militares foram responsabilizados por afastar os bacharéis em Direito da política. 
momentos distintos das políticas de ensino superior no Brasil. O primeiro ligado à intenção do Governo Central de criar uma escola responsável pela formação de nossa elite política. O segundo voltado à ampliação do ensino superior e à criação de dezenas de carreiras novas durante a década de 70 , como conseqüência direta da crise do ensino superior de 1968.

A criação intencional dos cursos jurídicos com objetivos políticos no Brasil, em 1827, e a rápida ampliação do número total de bacharéis na Câmara revelam uma bem sucedida campanha do Governo Central no intuito de homogeneizar a elite política nacional. De acordo com Venâncio Filho (1982), a escolha por uma política de ensino superior significou o abandono da instrução fundamental. Os parlamentares, preocupados com a formação "adequada" dos futuros deputados e senadores, deixaram de investir recursos na alfabetização e na ampliação dos liceus. A proclamação da República e a simultânea reforma que marcou o fim do monopólio estatal sobre as faculdades de Direito fizeram emergir a demanda do aparato burocrático por um significativo contingente de bacharéis em Direito que atendessem às necessidades estatais. A ampliação no número de escolas manteve acesa a participação dos bacharéis em Direito na Câmara. A despeito das intenções contrárias dos militares, o diploma jurídico continuou super- representado. Dessa forma, o reflexo da política de ensino superior do Imperador na Câmara pouco foi abalada pela tentativa dos militares, mesmo tendo declarado a intenção de afastar os bacharéis do poder. Se o fizeram nos cargos de nomeação direta, as eleições não afastaram o diploma jurídico dos cargos eletivos. Entre 1900 e 1930 o nível de representação manteve-se acima dos registrados entre 1842 e 1852.

A segunda alteração na política de ensino superior que marcou profundamente a presença dos bacharéis em Direito na política ocorreu em 1968. A despeito da tentativa declarada dos militares de afastar o diploma jurídico do poder, foi, aparentemente, uma alternativa indireta a maior responsável por esse distanciamento. A medida, nesse sentido, parece ter surtido efeito retardado, pois, ao longo do regime autoritário, os bacharéis ocuparam cerca de $50 \%$ das cadeiras na Câmara. Tendo esse número diminuído sensivelmente após o restabelecimento da democracia.

Em 1968, com a crise das vagas nos vestibulares, o governo mais preocupado com investimentos em infra-estrutura - entregou à 
iniciativa privada o controle do ensino superior no país. Entendido como um negócio, inúmeras faculdades foram sendo inauguradas. Para completar, dezenas de novas carreiras foram criadas e a tradição das engenharias, da Medicina e do Direito foi dividia com carreiras voltadas para a formação de professores para o ensino médio, administração de empresas etc. A redemocratização do país, ocorrida na década 80 , trouxe consigo uma nova gama de representantes de diversas carreiras na Câmara. A superioridade dos bacharéis em Direito foi mantida, mas desde 1987 não ultrapassou a casa dos trinta e oito pontos percentuais, o resultado mais baixo da história.

Por sua vez, a formação de nível superior de qualquer natureza não deixou de caracterizar, ao longo de quase dois séculos, menos de $80 \%$ do total de deputados. Isso demonstra que, diante das demais carreiras, o título jurídico já não exerce a mesma importância na Câmara. A ampliação do ensino superior parece ter alcançado melhores resultados no afastamento dos bacharéis do que qualquer outra tentativa mais explícita das forças armadas de alijar os juristas do poder. Resta esclarecer que o diploma de Direito ainda é o mais presente entre os cidadãos formados no Brasil, o que pode significar que esta superioridade seja um mero reflexo desta proporção.

\section{Crétioo 1}

\section{Percentual de Bacharéis em Direíto na Camara dos Deputados}

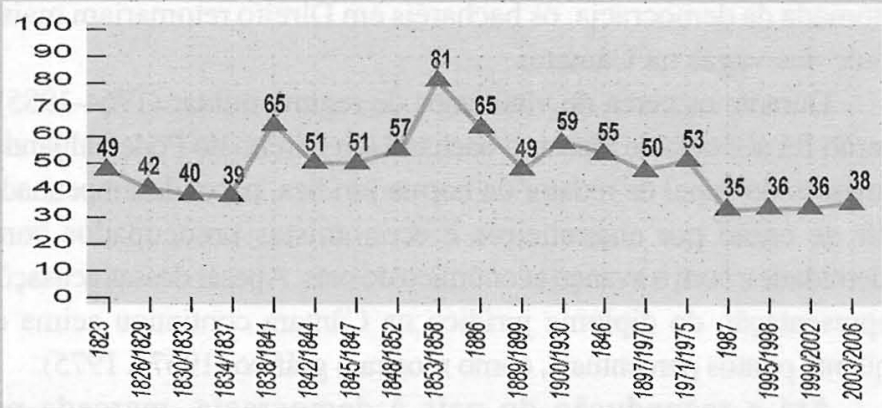

Fonte: Dantas (2002) 
De acordo com o gráfico 1 é possível visualizar os argumentos defendidos anteriormente. Entre 1823 e 1837 a escola de Direito de Coimbra ainda alimentava as fileiras políticas do Brasil. A discreta queda dos índices nos quatro pontos deste período revela a intenção do governo brasileiro de romper os laços com a antiga metrópole. A partir de 1834 surgem os primeiros deputados com formação nacional, mas somente a partir de 1838, quando as escolas jurídicas completam 10 anos de existência, é que a presença de bacharéis supera a metade das cadeiras.

Enquanto durou o monopólio do governo sobre o ensino superior, e a declarada intenção de fazer dos cursos jurídicos a "antesala" da representação política do país, os índices de bacharéis em Direito na Câmara mantiveram-se acima dos 50 pontos percentuais, tendo alcançado $81,2 \%$ entre 1853 e 1858 . Nesse sentido, como vimos, os objetivos do governo eram plenamente contemplados: além de monopolizar o ensino jurídico, formavam ao seu modo a elite dirigente do país. O sucesso dessa política de ensino superior marcaria profundamente a história do país.

Findo o período imperial, os militares voltaram-se contra a intencional presença dos bacharéis em Direito na política. Na década posterior à proclamação da República (1889-1899), o índice de diplomas jurídicos entre os deputados caiu para menos da metade do total de cadeiras, sendo que os representantes das forças armadas preencheram tais vagas. Com a ocupação da presidência por um civil, os índices de ocupação voltaram a superar os cinquienta pontos percentuais (19001930). Com o Estado Novo o Congresso foi fechado, mas em 1946, com a retomada da democracia, os bacharéis em Direito retomariam mais da metade das vagas na Câmara.

Durante os cerca de vinte anos de regime militar (1964-1985), o governo foi acusado de afastar o bacharel em Direito do Poder, alijando-o até mesmo do papel de redator da norma jurídica, papel desempenhado a partir de então por engenheiros e economistas preocupados com a modernidade e com o avanço econômico do país. Apesar dessas acusações, a representação do diploma jurídico na Câmara continuou acima dos cinqüenta pontos percentuais, como mostra o gráfico (1967 a 1975).

Até a recondução do país à democracia, marcada pela promulgação da Constituição de 1988, os bacharéis em Direito 
mantiveram a metade dos assentos da Câmara dos Deputados. A queda para índices próximos a 35\%, a partir de 1987, pode ser atribuída a uma nova política de ensino superior para o país, iniciada durante o regime militar. Intencionalmente, ou não, o governo das forças armadas, avesso à presença dos bacharéis em Direito na política (FARIA; MENGE, 1979), viabilizou uma maior divisão de cadeiras entre as carreiras de ensino superior na Câmara. Ao contrário do que poderíamos supor, a retomada da democracia não trouxe consigo um aumento na parcela de deputados sem titulação acadêmica (de qualquer natureza). O parlamentar com formação universitária ainda representa mais de $80 \%$ da Câmara.

\section{Conclusão: novas carreiras e a retomada da intencionalidade}

Ao longo de nossa argumentação, foi possível perceber que o diploma de Direito ainda é o título acadêmico mais representado entre os deputados federais no Brasil, sendo o advogado o profissional mais presente na Câmara. Apesar de manter esse domínio, a carreira deixou de estar vinculada aos interesses oficiais de formação de uma elite política, como ocorreu no século XIX, para concentrar-se ainda nas primeiras décadas do século XX no atendimento às mais variadas demandas por instituições jurídicas.

A análise das políticas de ensino superior, com ênfase na carreira jurídica, permitiu verificar que elas tiveram papel fundamental na aproximação e no afastamento do bacharel em Direito da política nacional. A presença proposital dos juristas na elite dirigente do século XIX e, mais tarde, a proliferação de outras carreiras e a massificação desordenada do ensino jurídico, sobretudo nas décadas de 70 e de 90 , são fatos que corroboram essa afirmação.

\section{O surgimento de novas carreiras na política}

Ao mesmo tempo que o governo permitiu a proliferação indiscriminada de escolas jurídicas, contribuindo para desarticular a força contestatória desse grupo de estudantes (FARIA; MENGE, 1979), novas carreiras proliferaram e ganharam espaço no meio acadêmico e 
no campo político. O maior exemplo é o curso de Administração de Empresas, que surgiu no início da década de 70 e nos anos 90 passou a oferecer mais vagas que as escolas de Direito (SAMPAIO, 2000).

A formação dos deputados de hoje parece ser o primeiro reflexo das medidas adotadas em 1968, uma vez que não houve um aumento intencional de outras carreiras na vida pública, mas um maior equilíbrio entre elas. A diversificação de cursos criou um significativo contingente de interessados na política, assim como afastou a quase exclusiva presença de bacharéis em Direito, que, somados aos médicos, engenheiros e militares respondiam por quase a totalidade dos postos políticos até os anos 70 do século XX. Restaria saber se num futuro próximo os bacharéis em Administração de Empresas, por exemplo, não ocuparam um espaço maior, considerando-se que em termos de oferta no "mercado" educacional, o número de vagas já supera o das demais escolas.

Esse argumento de divisão do espaço político entre as carreiras do ensino superior encontra resistência no trabalho de Simões Neto (1983) que afirma não haver motivos para a redução da presença do bacharel em Direito na política, uma vez que esse grupo possui um compromisso com os ideais da formação do Estado Moderno e do Estado Democrático de Direito.

A despeito do surgimento de novas carreiras representadas na Câmara como conseqüência de políticas de ensino superior surgidas no final dos anos 60 , é interessante notar que entre os juristas vige a intenção de reconduzir a carreira ao seu "local tradicional". A análise do discurso de publicações da Ordem dos Advogados do Brasil sobre o ensino jurídico permite-nos supor que o que se espera do "bacharel em Direito ideal" ${ }^{\prime 23}$ reconduz esta categoria ao eixo central da vida política nacional. Sendo a OAB defensora da tese de que os bacharéis devem promover e garantir a cidadania, assim como ser agentes críticos da sociedade, a presença intencional do diploma jurídico na política, mesmo que encoberta por um discurso de participação social, volta a fazer parte dos anseios dos responsáveis por esses cursos.

${ }^{23} \mathrm{O}$ bacharel em Direito ideal é o sujeito tecnicamente preparado para operar a norma jurídica e, ao mesmo tempo, preparado para entender os problemas sociais do país. É também, neste caso, entendido como o "bacharel cidadão". 
Enquanto alguns autores defendem essa idéia de forma mais discreta, como Lôbo (2000) ao afirmar que um dos grandes desafios da educação jurídica é capacitar o profissional para atuar na sociedade do século XXI - a qual traz consigo questões não resolvidas no século $\mathrm{XX}$, como o respeito aos direitos humanos, a democratização, a qualidade de vida e a justiça social, outros autores, como Pinto (2000) são mais explícitos. Este autor acredita que a presença dos economistas na política fez com que se perpetuassem os vícios, a tendência à fuga dos encargos sociais e a institucionalização do "jeitinho brasileiro". Esta nova classe dirigente, segundo o autor, teria sacrificado valores sociais em favor de planos econômicos, e o alto poder cívico, fundado em "corajoso amor à liberdade" dos advogados, deve servir de exemplo para a divulgação, por parte das escolas, do ideal de cidadania contido no discurso político.

Bastos (1997) entende como positiva a convivência dos bacharéis em Direito com profissionais de outras carreiras, seja no poder, seja com vistas à criação de um novo currículo para os cursos jurídicos, que a partir de 1994 passaram a priorizar a formação de profissionais aptos a responder às demandas da cidadania e ao desenvolvimento econômico e científico. Venâncio Filho (1982) afirma que, em virtude da inadequação do ensino jurídico, é inevitável a substituição do bacharel em Direito por engenheiros, economistas e administradores até mesmo na redação da norma jurídica. Os advogados ficaram isolados na sociedade, pois não evoluíram, ficando presos à formação característica do século XIX. A solução para esta situação seria um reequilíbrio de posições, que se daria a partir de um ensino mais adequado, no qual fosse compreendido o papel do advogado diante do desenvolvimento econômico brasileiro. Azevedo (1996), por sua vez, demonstra que a condução do país deveria ser retomada pelos bacharéis em nome da "tradição nacional".

É evidente que o Estado não tem mais o compromisso intencional de formar bacharéis em Direito destinados a ocupar cargos políticos. Partindo desse pressuposto, uma categoria preocupada com o desenvolvimento de valores da democracia, com a cidadania e com o cumprimento dos direitos dos cidadãos apenas elevaria a qualidade dos representantes postos à disposição do eleitorado. A presença do 
bacharel na política, respeitando as regras do jogo e o desejo da $\mathrm{OAB}$ de elevar o nível desse ensino parece legítima do ponto de vista político. Estando a entidade preocupada com o caráter ético de seus inscritos, o movimento de "recondução" 24 mostra-se exclusivamente vinculado à melhoria do ensino jurídico do país. A formação do "bacharel ideal" ou do "bacharel cidadão" responderia por tal retomada e, nesse sentido, a sociedade ganharia em dobro: com uma formação qualificada da carreira que mais diploma bacharéis no Brasil e com a representação política de uma categoria preocupada com questões indispensáveis ao desenvolvimento democrático. Restaria saber até que ponto não há traços de corporativismo nessas propostas. O ideal seria que a sociedade, e não só os cursos de Direito, fosse orientada pelos princípios da ética, da cidadania, dos direitos humanos e do "bacharel cidadão". Nesse sentido, de acordo com Felix (2001), o advento da Constituição de 1988 fez com que o bacharelado em Ciências Jurídicas voltasse a exercer o fascínio de outrora - perdido durante o regime militar apesar do aumento do número de estabelecimentos de ensino dessa natureza. Segundo o autor, a instauração do Estado de Direito e o estabelecimento do regime democrático fizeram ressurgir a crença no respeito às leis. Resta, porém, entender se essa renovação pode significar uma reedição da posição vivida anteriormente.

As propostas de algumas faculdades já revelam estar elas próprias interessadas em retomar a intenção de formar homens para a política. O curso de Direito da Universidade de São Paulo, por exemplo, evoca sua tradição na formação de homens públicos, o que torna claro o compromisso da escola com a política nacional: "A Faculdade teve um papel preponderante na história das instituições políticas e sociais do Brasil, pois por ela passaram nove presidentes da República de Prudente de Moraes até Jânio Quadros; doze governadores de São Paulo, após a República, desde Américo Brasiliense, passando por Jânio Quadros, Abreu Sodré até Franco Montoro" (USP, 2002).

${ }^{24}$ Como percebemos, o termo "recondução" utilizado por alguns dos estudiosos da $\mathrm{OAB}$ parece esvaziado de significado, quando notamos a maciça e constante presença de bacharéis em Direito nos órgãos políticos representativos. 
A Universidade Católica de Santos (2002) parece salientar esses mesmos valores. Segundo dados da instituição, a escola de Direito "conquistou, ao longo dos anos, uma excelente projeção no cenário jurídico nacional, tornando-se conhecida pela tradição de formar profissionais que se tornaram juizes, promotores, delegados de polícia, políticos de prestígio, procuradores de justiça, e diplomatas".

No caso da Pontifícia Universidade Católica de Campinas (2002), a carreira política aparece como uma possibilidade a ser considerada no futuro e não como uma tradição, como ocorre na USP e na UniSantos.

O curso de Direito forma profissionais que poderão atuar como advogados, liberais ou com vínculo empregatício. Mediante concursos públicos de provas e títulos, poderão ingressar na Magistratura, no Ministério Público, na Procuradoria, na Polícia, galgando os vários degraus das carreiras, entrando como substitutos, podendo chegar a Ministro. Poderão, ainda, optar pelas carreiras diplomática ou política, nesta última concorrendo a cargos públicos eletivos ou de assessoramento.

Nota-se, neste caso, que a faculdade oferece duas possibilidades vinculadas à política: a ocupação de um posto de assessor e a obtenção de um cargo eletivo, que, diga-se de passagem, exige como pré-requisitos apenas: alfabetização, filiação partidária, domićlio eleitoral e idade.

O que podemos concluir é a existência de uma preocupação da $\mathrm{OAB}$ com a retomada da participação do bacharel em Direito na política nacional. Se tal representação se fizer por vias democráticas, aliadas a uma melhoria no combalido ensino jurídico nacional, certamente o país será o grande beneficiado. Em contrapartida, resta destacar que as políticas de ensino superior adotadas no regime militar, apesar de terem permitido uma expansão desqualificada da estrutura universitária, abriram um leque maior de possibilidades, tanto em termos meramente quantitativos quanto no que diz respeito a um aumento no número de carreiras disponíveis. Sob este ponto de vista, a diminuição da hegemonia dos bacharéis em Direito na Câmara também deve ser entendida como positiva, pois possibilitou uma democrática ascensão de novos representantes preocupados com interesses igualmente legítimos vistos sob ângulos diferentes.

Por fim, não podemos deixar de lembrar que profissionais de outras carreiras já garantiram espaço na política nacional e que o desejo de um 
determinado segmento profissional de voltar a ocupar o cenário político em nome de uma tradição esbarra, principalmente, no desejo do eleitor. Este, em última instância, é quem resolve que tipo de representante será eleito. Independente de o cidadão saber ou não se seu candidato preferido é bacharel em Direito, atualmente não nos parece ser a posse desse título um diferencial capaz de determinar a escolha de um político.

\section{Referencias}

ADORNO, Sérgio. Os Aprendizes do Poder: o bacharelismo liberal na política brasileira. Rio de Janeiro: Paz e Terra, 1988.

AZEVEDO, Álvaro Villaça. Formação do Advogado - o que fazer? In: ORDEM DOS ADVOGADOS DO BRASIL. OAB - Ensino Jurídico - Novas Diretrizes Curriculares. Brasília: Conselho Federal da OAB, 1996.

BARRETO, Vicente. O Estado de Direito e os cursos jurídicos: Debate original. In: WANDER BASTOS, Aurélio. (Coord.) Os cursos jurídicos e as elites políticas brasileiras. Brasília: Câmara dos Deputados, 1978.

BASTOS, Aurélio W. O ensino jurídico no Brasil e as suas personalidades históricas: uma recuperação de seu passado para reconhecer seu futuro. In: ORDEM DOS ADVOGADOS DO BRASIL. Ensino Jurídico OAB - 170 anos de cursos jurídico no Brasil. Brasília: OAB Conselho Federal, 1997.

BRAGA, Sérgio Soares. Quem foi quem na Assembléia Constituinte de 1946. Brasília: Câmara do Deputados, 1998.

CÂMARA DOS DEPUTADOS. Deputados Brasileiros - Repertório Bibliográfico - 1999/2003 - 51 A Legislatura. Brasília, 1999.

CÂMARA DOS DEPUTADOS. Deputados Brasileiros - Repertório Bibliográfico - 1976/1970. Brasília, 1968.

CARVAlHO, José Murilo de. A Construção da Ordem: elite política imperial. Brasília: Universidade de Brasília, 1981.

DANTAS, Humberto. Ensino Jurídico e Classe Política. 2002. Dissertação (Mestrado) - Faculdade de Filosofia, Letras e Ciências Humanas da Universidade de São Paulo, São Paulo. 
FALCÃO NETO, Joaquim Arruda. Os cursos Jurídicos e a Formação do Estado Nacional. In: WANDER BASTOS, Aurélio. (Coord.). Os cursos jurídicos e as elites políticas brasileiras. Brasília: Câmara dos Deputados, 1978.

FARIA, José Eduardo; MENGE, Claudia de Lima. A Função social da dogmática e a crise do ensino jurídico e da cultura jurídica brasileira. Revistas Dados, n.21, p.87-113, 1979 .

FELIX, Loussia P. Musse. Da reinvenção do ensino jurídico: considerações sobre a primeira década. In: ORDEM DOS ADVOGADOS DO BRASIL. OAB Recomenda - um retrato dos cursos jurídicos. Brasília, 2001.

HOLANDA, Sérgio Buarque de (Org.). História Geral da Civilização Brasileira: livro II o Brasil Monárquico - declínio e queda do império. Rio de Janeiro: Bertrand Brasil, 1997.

LÔBO, Paulo Luiz Neto. Ensino jurídico: realidade e perspectivas. In: ORDEM DOS ADVOGADOS DO BRASIL. OAB Ensino Jurídico - Balanço de uma perspectiva. Brasília, 2000.

MARTINS RODRIGUES, Leôncio. Quem é Quem na Constituinte: uma análise sócio-política dos partidos e deputados. São Paulo: OESP / Maltese, 1987.

PINTO, Adriano. Autonomia universitária, sentimentos sociais e confrontos de qualidade do ensino jurídico. In: ORDEM DOS ADVOGADOS DO BRASIL. OAB Ensino Jurídico - Balanço de uma perspectiva. Brasília, 2000.

PONTIFÍCIA UNIVERSIDADE CATÓLICA DE CAMPINAS. Descrição do curso de Direito. Disponível em: <http://www.puccamp.br/graduacao/humanas/ cursos/curso_10.htm>. Acesso em: 2002.

RODRIGUES, José Honório. A Assembléia Constituinte de 1823. Petrópolis: Vozes, 1974.

SAMPAIO, Helena. Ensino Superior no Brasil - o setor privado. São Paulo: Hucitec / FAPESP, 2000.

SENADO FEDERAL. Senadores Constituintes - 48 legislatura - 1987-1991. Brasília, 1987.

SIMÕES NETO, Francisco Teotônio. Os bacharéis na política e a política dos bacharéis. 1983. Tese (Doutorado) - Faculdade de Filosofia, Letras e Ciências Humanas da Universidade de São Paulo, São Paulo.

UNISANTOS. Universidade Católica de Santos. Curso de Direito. Disponível em: <www.unisantos.br/direito>. Acesso em 2002. 
UNIVERSIDADE DE SÃO PAULO. Curso de Direito. Disponível em: <http:// www.vestibularl.com.br/duvidas/direito.htm>. Acesso em : 2002.

VENÂNCIO FILHO, Alberto. Das Arcadas ao Bacharelismo (150 anos de ensino jurídico no Brasil). 2.ed. São Paulo: Perspectiva, 1982.

\section{Abstract}

Law bachelors are, and always have been, the most widely represented class in brazilian politics. The constitution of the House of Representatives throughout history has reflected this reality since the Empire. This representation has varied, however, during the last two centuries and especially after the 1988 Constitution. The following article intends to show that the representation of law bachelors in national politics, which can be measured by the number of members of the House of Representatives who have careers in Law, is related to the adoption of college education policies by different governments throughout almost two centuries.

Key words: political class, law education, college education policies 